\title{
EFFECT OF PIX AND POTASSIUM CITRATE ON GROWTH, PRODUCTIVITY FIBER QUALITY AND YARN ON EGYPTIAN COTTON
}

\author{
(Received:20.8.2014)
}

\author{
By \\ H. S. A. Ahmed* , R. M. Y Zewail and A. A.Hassan* \\ Botany Department, Faculty of Agriculture, Benha University, Egypt. \\ *Cotton Research Institute, Agricultural Research Center, Giza, Egypt
}

\begin{abstract}
Two field experiments were conducted at the Agriculture Experimental and Research Station, Faculty of Agriculture, Moshtohor, Benha University, during 2012 and 2013 seasons to study the effect of spraying Mepiquate chloride (Pix) at 100,200 and $250 \mathrm{mg} / \mathrm{l}$, potassium citrate $\left(\mathrm{K}_{2}\right)$ at 500 and $1000 \mathrm{mg} / \mathrm{l}$ and the combination of pix at $200 \mathrm{mg} / \mathrm{l}+$ potassium citrate at $500 \mathrm{mg} / \mathrm{l}$ as foliar spray at 50,70 and 90 days after sowing, on different growth and plant yield characteristics including fiber properties, minerals, carbohydrates and crude protein contents in the two cotton cultivars Giza 86 and Giza 88. The results showed that the different applied treatments increased growth characteristics, i.e., leaf and branch number, total leaf area/plant, dry weight/plant and total chlorophyll (SPDS) in Giza 86 and Giza 88 cotton cultivars at 120 days after sowing during 2012 and 2013 seasons. Maximum increase was with pix at $200 \mathrm{mg} / \mathrm{l}+$ potassium citrate at $500 \mathrm{mg} / \mathrm{l}$ in both seasons. Meanwhile plant height decreased with different applied treatments in the two assigned seasons. Also, Yield and yield components i.e., bolls number and weight, seed cotton yield/plant and seed index significantly increased with different treatments and gave the highest value with pix at $200 \mathrm{mg} / \mathrm{l}+$ potassium citrate at $500 \mathrm{mg} / \mathrm{l}$ in the two cultivars in both seasons. In addition, span length SL2.5\%, SL 50\%, UR $\%$, ML, UHM, UI\%, SL66.7\%, Rd\%, elongation and Strength. Fiber tests were increased with different treatments. On the other hand, different treatments decreased SFC \%, C.V\%, b, MIC, C.V\%, Thin Places, Thick Paces and Neps in Giza 86 during 2012 and 2013 seasons. But, in Giza 88 the different treatments increased SL 50\%, UR\%,UHM, SL 66.7\%, elongation, Mic. and Neps during 2012 and 2013 seasons. Different applied treatments decreased SL2,5\%, ML, UL \%, C.V. \% Rd, STR, C.V \%, Thin Places and Thick Places during 2012 and 2013 seasons. Furthermore, some minerals and bio constituents were increased with different applied treatments.
\end{abstract}

Key words: Egyptian cotton, Giza 86, Giza88, pix, potassium citrate, growth, yield, fiber properties, Yarn properties.

\section{INTRODUCTION}

Egyptian cotton (Gossypium barbadense L.) is the most important commercial fiber crop in Egypt. Cotton plays a key role in the economic activity. It is the oldest among the commercial crops and is termed as white gold. Plant growth parameters are used to improve lint yield, fiber quality and yarn properties. Obviously, the best means to achieve these aims is through the use of desirable genotypes in the form of welladapted high-yielding varieties. Plant growth regulators"PGR" When produced endogenously by plants, they are referred to plant hormones. when used as either naturally or synthetic compounds that are applied directly to a target plant to alter its physiological processes or its structure to improve quality. Increaseing yield, or facilitate harvesting control, prevent undesirable late vegetative growth of plants, and enhancing fruiting could be achieved. Like promoters, inhibitors play a key role in control mechanism of plant growth by interacting with metabolic processes such as nucleic acid and protein synthesis. Of these substances is Pix (N,N-dimethyl piperidinium chloride), commonly referred to as Mepex, Topit, and Mepiquate Chloride which consists of $4.2 \% \mathrm{~N}$, $\mathrm{N}$-dimethyl piperidinium chloride, a quaternary ammonia compound (Mohammad et al., 2007, Ahmed 2010 ; Najma et al., 2000 and Niakan et al., 2012). 
Pix, is the first plant growth regulator that has significant effect on cotton growth and yield. Plant growth regulators such as pix decrease cotton vegetative growth by inhibiting gibberellic acid synthesis, a common plant hormone, which in turn, decreases cell elongation. Also, it suppresses vegetative growth in cotton, mainly by reducing the main stem and fruiting branch interned lengths (Ahmed 2010).

On the other hand, the importance of $\mathrm{K}_{2}$ fertilization in Egyptian agriculture has become more apparent since the establishment of the High Dam, which resulted in the deposition of the suspended Nile silt upstream from the formed lake. This Nile silt was a source of Kbearing minerals that enriched the soils during the seasonal floods. Potassium affects respiration, photosynthesis, chlorophyll development, water content of leaves, carbon dioxide $\left(\mathrm{CO}_{2}\right)$ assimilation, and carbon movement (Sangakkara et al., 2000 and Ahmed, 2002). Also potassium, has an important role in the translocation of photosynthesis from sources (leaves) to sinks (bolls), (Cakmak et al.,1994). Potassium deficiencies can limit the accumulation of crop biomass. This has been attributed to a reduction in the partitioning of assimilates to the formation of leaf area and a decrease in the efficient use of intercepted radiation for the production of above-ground biomass. In this respect, Colomb et al. (1995) and Pettigrew (1999) stated that part of the overall effect of $K_{2}$ deficiency was reducing the amount of photosynthetic available for reproductive sinks, which produced changes in lint yield, fiber quality and yarn properties.

Therefore, this study aimed to determine the effect of different applied pix and potassium on growth and the balance between vegetative and reproductive growths to attain efficient cotton production, maximizing yield and high quality fiber properties for the Egyptian cotton cultivars Giza 86 and Giza 88.

\section{MATRIAL AND METHODS}

These experiments were conducted at the Agriculture Experimental and Research station, Faculty of Agriculture, Moshtohor, Benha University Egypt. Experiments were carried out during 2012 and 2013 seasons to study the effect of foliar spray with Mepiquate chloride (Pix) at 100,200 and $250 \mathrm{mg} / \mathrm{l}$ and potassium citrate $\left(\mathrm{K}_{2}\right)$ at $500 \mathrm{mg} / \mathrm{l}$ and $1000 \mathrm{mg} / \mathrm{l}$ as well as its assigned combination on growth, yield components and fiber properties for the Egyptian cotton Giza 86 and Giza 88 cultivars.

The design of the experiment was randomized complete block design arrangement with four replicates. Plot area was $10.5 \mathrm{~m}^{2}(5$ ridges, $3.5 \mathrm{~m}$ long and $60 \mathrm{~cm}$ a part). Distance between hills was $25 \mathrm{~cm}$ leaving two plants hill ${ }^{-1}$ at thinning time (after five weeks from sowing). Cotton seeds were sown according to the usual dry method on $19^{\text {th }}$ and $18^{\text {th }}$ April in 2012 and 2013 seasons, respectively. Foliar sprays of different treatments were applied at 50,70 and 90 days after sowing i.e Mepiquate chloride (Pix) at 100, 200 and $250 \mathrm{mg} / \mathrm{l}$; potassium citrate $\left(\mathrm{K}_{2}\right)$ at 500 and $1000 \mathrm{mg} / \mathrm{l}$ and the combination of pix at $200 \mathrm{mg} / \mathrm{l}+$ potassium citrate at 500 $\mathrm{mg} / \mathrm{l}$ as well as distilled water for the control. The other required culture practices for growing cotton plants (fertilizers, irrigation pest and diseases control) were followed as recommended.

The experiments were laid out in a clay soil; its physical and chemical properties are shown in Table (1). Each experiment included 5 treatments for each cultivar.

\subsection{Recording of the Data}

The plants were taken at random from each experimental plot at 120 days after sowing to determine some growth attributes, i.e., plant height, no. of leaves, leaf area were measured by the disc method according to Johnson (1967), total dry weight and total chlorophyll content by chlorophyll meter (SPDS) Model SPAD 402.

\subsection{Yield components, fiber properties and yarn properties}

At harvest (i.e., at 180 days after sowing) ten guarded plants from each experimental unit were chosen randomly taken the central row and the following traits were estimated; no. of sympodial branches/ plant, no. of open bolls/ plant, boll weight $(\mathrm{g})$, seed index $(\mathrm{g})$, and seed cotton yield plant $^{-1}(\mathrm{~g})$.

2.2.1. Fiber properties The following fiber properties were measured using high volume Instrument (HVI). High volume fiber test system according to (A.S.T.M: D 46050 - 1998).

2.2.1.1. Fiber length parameters Fiber length at upper half means (U.H.M) mm. uniformity index (U.I).

2.2.1.2. Fiber bundle tensile Fiber strength in gram / tex. - Fiber elongation \%: the percentage of elongation, which occurs before a fiber bundle breaks. 
Table (1):Physical and chemical properties of the experimental soil at the Farm, Faculty of Agriculture, Moshtohor during 2012 and 2013 seasons.

\begin{tabular}{|c|c|c|}
\hline \multirow[t]{2}{*}{ Properties } & \multicolumn{2}{|c|}{ Seasons } \\
\hline & 2012 & 2013 \\
\hline \multicolumn{3}{|c|}{ Particle size distribution ( mechanical analysis } \\
\hline Course sand \% & 7.21 & 6.54 \\
\hline Find sand \% & 25.92 & 26.62 \\
\hline Silt \% & 12.86 & 13.62 \\
\hline Clay \% & 51.98 & 53.22 \\
\hline Texture grade & Clay & Clay \\
\hline \multicolumn{3}{|c|}{ Chemical analysis } \\
\hline E.C. & 2.15 & 2.18 \\
\hline pH $(1: 2.5)$ & 8.10 & 8.08 \\
\hline $\mathrm{CaCo}_{3} \%$ & 3.45 & 3.02 \\
\hline O.M \% & 2.13 & 2.20 \\
\hline N \% ( total) & 0.165 & 0.165 \\
\hline $\mathbf{N}(\mathbf{p p m})$ (available) & 51.05 & 52.63 \\
\hline P \% ( total) & 0.116 & 0.118 \\
\hline $\mathbf{P}(\mathbf{p p m})$ (available) & 19.4 & 20.81 \\
\hline K \% ( total) & 0.65 & 0.63 \\
\hline K(ppm) (available) & 937.75 & 996.35 \\
\hline \multicolumn{3}{|c|}{ Soluble cations and anions ( $\mathrm{ppm}$ ) } \\
\hline $\mathrm{Ca}^{++}$ & 185.6 & 192.6 \\
\hline $\mathrm{Mg}^{++}$ & 40.06 & 41.83 \\
\hline $\mathbf{K}^{+}$ & 42.64 & 41.81 \\
\hline $\mathrm{Na}^{+}$ & 191.42 & 191.25 \\
\hline $\mathrm{Cl}^{-}$ & 222.83 & 252.26 \\
\hline $\mathrm{Co}_{3}^{--}$ & 0.00 & 0.00 \\
\hline $\mathrm{H} \mathrm{Co}_{3}^{-}$ & 344.28 & $\mathbf{3 6 5 . 3 7}$ \\
\hline $\mathrm{So}_{4}^{--}$ & 491.96 & 461.12 \\
\hline
\end{tabular}

2.2.1.3. Fineness characters Fiber fineness (Micronaire reading). Fiber fineness was expressed as micronaire instrument reading, measured by (HVI).

2.2.1.4. Color attributes values Reflectance $(\mathrm{Rd} \%)$ and Yellowness (+b)

2.2.1.5. KEISOKKI $\mathrm{kcf}-\mathrm{v} / \mathrm{ls}$ version 1.29.3. The following fiber properties were measured using Keisokki (2013) kcf-v/ls version 1.29.3. Instrument High volume fiber Length test system.

2.2.1.6 Fiber length parameters Coefficient of variation c.v \% for length - Spain length at $66.7 \%$ - Spain length at 50 SL \% -
Uniformity Ratio UR \% - Short Fiber content (S.F.C. \%).

\subsubsection{Yarn properties}

The R.S.S second part was spun fiber into (R.S.S) Ring spinning system $60^{\mathrm{s}}$ carded count yarns at 3.6 (T.M.) for tests of yarn properties. Skein strength was measured according to ASTM: D-1578-67, (1998). Neps, thick places, thin places per/100 meter and yarn evenness (C.V \%) was measured by Uster tester 3 according to ASTM: D-1425-60, (1998). All fiber tests were performed at the laboratories of the cotton Research Institute, Agricultural Research Center. Fiber tests were conducted at a relative humidity of $65 \pm 2 \%$ and a temperature of $21 \pm 2^{\circ} \mathrm{C}$ to determine.

\subsection{Chemical analysis}

Samples of cotton leaves at 100 days after sowing were taken to determine at 4 upper sympodial, total nitrogen as described by Horneck and Miller (1998), phosphorus by Sandell (1950), potassium by Horneck and Hanson (1998). While Ca, Mg, Fe, $\mathrm{Zn}$ and Cues described by A.O.A.C. (1990). The Crude protein was calculated according to the followings equation: Crude protein $=$ total nitrogen x 6.25 (A.O.A.C., 1990). Total carbohydrates, were determined according to Dubois et al., (1956).

\subsection{Statistical analysis}

All data were statistically analyzed and the means were compared using the least significant difference Test (LSD) at 5\% level according to Snedecor and Cochran (1989).

\section{RESULTS AND DISCUSSIONS}

\subsection{Growth characteristics}

Data in Table (2) indicate that, leaf number, number of branches, total leaf area/plant, dry weight/plant and total chlorophyll SPDS at 120 days after sowing were significantly affected with different applied treatments, i.e., Mepiquate chloride (Pix) at 100, 200 and $250 \mathrm{mg} / \mathrm{l}$, potassium citrate $\left(\mathrm{K}_{2}\right)$ at $500 \& 1000 \mathrm{mg} / 1$ and combination of pix at $200 \mathrm{mg} / \mathrm{l}+$ potassium citrate at $500 \mathrm{mg} / 1$ also, as shown in Table (2) the highest values of increase were obtained with pix at $200 \mathrm{mg} / \mathrm{l}+$ potassium citrate at $500 \mathrm{mg} / \mathrm{l}$ in Giza 86 and Giza 88 C vs., during 2012 and 2013 seasons. On the other hand, plant height decreased by using pix treatments in the different levels (100, 200 and $250 \mathrm{mg} / \mathrm{l})$ during 2012 and 2013 seasons. Meanwhile, potassium citrate at $500 \& 1000 \mathrm{mg} / \mathrm{l}$, significantly 
Table (2): Effect of pix and potassium citrate on growth attributes in some Egyptian cotton, cultivars during 2012 and 2013 seasons.

\begin{tabular}{|c|c|c|c|c|c|c|c|c|c|c|c|c|}
\hline \multirow{3}{*}{$\begin{array}{l}\text { Characteristics } \\
\text { cultivars }\end{array}$} & \multicolumn{12}{|c|}{ Vegetative growth } \\
\hline & \multicolumn{2}{|c|}{ Plant height } & \multicolumn{2}{|c|}{$\begin{array}{l}\text { Leaves } \\
\text { number }\end{array}$} & \multicolumn{2}{|c|}{$\begin{array}{l}\text { Number } \\
\text { of branches }\end{array}$} & \multicolumn{2}{|c|}{$\begin{array}{c}\text { Total } \\
\text { leaf area } \mathrm{cm} 2\end{array}$} & \multicolumn{2}{|c|}{$\begin{array}{c}\text { Dry } \\
\text { weight g }\end{array}$} & \multicolumn{2}{|c|}{$\begin{array}{c}\text { Total } \\
\text { chlorophyll }\end{array}$} \\
\hline & G 86 & G 88 & G 86 & G 88 & G 86 & G 88 & G 86 & G 88 & G 86 & G 88 & G 86 & G 88 \\
\hline \multicolumn{13}{|c|}{ Season 2012} \\
\hline Control & 165.00 & 156.42 & 55.33 & 42.66 & 23.00 & 22.33 & 2321.2 & 2140.5 & 80.12 & \begin{tabular}{|l|l|}
55.18 \\
\end{tabular} & 65.25 & 78.52 \\
\hline Pix 100 mg/l & 30.14 & 151.22 & 65.00 & 46.33 & 25.00 & 24.66 & 2382.2 & 2312.3 & 82.34 & 62.56 & 90.56 & 91.62 \\
\hline Pix 200 mg/l & 5.26 & 149.26 & 67.66 & 48.33 & 26.66 & 25.00 & 2415.1 & 2352.2 & 86.23 & 69.30 & 108.56 & 112.23 \\
\hline Pix 250 mg/l & 128.32 & 148.72 & 69.33 & 50.66 & 29.00 & 27.33 & 2480.2 & 2448.6 & 87.43 & 73.12 & 115.12 & 117.81 \\
\hline $\mathrm{k}_{2} 500 \mathrm{mg} / \mathrm{l}$ & 165.16 & 159.22 & 72.66 & 53.00 & 28.66 & 29.66 & 2623.3 & 2518.1 & 90.73 & 78.25 & 112.46 & 120.15 \\
\hline $\mathrm{k}_{2}$ 1000mg/l & & & & & & & & & 91.15 & & 113.40 & \\
\hline Pix $200+k_{2} 500$ & 162.11 & 155.20 & 75.33 & 55.66 & 29.00 & 32.66 & 2685.12 & 2572.14 & 91.15 & 81.25 & 120.16 & 123.52 \\
\hline LSD $5 \%$ & & & 1.85 & & 1.23 & 1.35 & & 10.23 & 2.26 & 2.45 & \begin{tabular}{|l|l|}
2.42 \\
\end{tabular} & 2.92 \\
\hline \multicolumn{13}{|c|}{ Season 2013} \\
\hline Control & 160.15 & 156.42 & 60.66 & 42.66 & 23.33 & 22.33 & 2372.1 & 2140.5 & 81.18 & 55.18 & 62.22 & 75.33 \\
\hline Pix 100 mg/l & 132.13 & 151.22 & 63.33 & 46.33 & 25.66 & 24.66 & 2386.3 & 2312.3 & 83.46 & 62.56 & 85.14 & 90.52 \\
\hline Pix 200 mg/l & 127.39 & 149.26 & 68.33 & 48.33 & 27.33 & 25.00 & 2425.6 & 2352.2 & 89.22 & 69.30 & 101.2 & 110.16 \\
\hline Pix 250 mg/l & 129.42 & & 70.00 & 50.66 & 29.66 & 27.33 & 2493.3 & 2448.6 & 82.12 & 73.12 & 110.15 & 115.75 \\
\hline $\mathbf{k}_{2} 500 \mathrm{mg} / \mathrm{l}$ & 167.19 & 159.22 & 73.00 & 53.00 & 29.00 & 29.66 & 2626.4 & 2518.1 & 91.81 & 78.25 & 107.30 & 118.22 \\
\hline 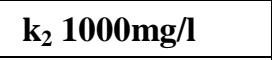 & 167.20 & 160.1 & 73.66 & 54.66 & 29.66 & 30.33 & 2641.3 & 2521.2 & 92.70 & 78.82 & 110.20 & 120.46 \\
\hline Pix $200+k_{2} 500$ & 159.25 & 155.20 & 76.66 & 55.66 & 30.33 & 32.66 & 2692.74 & 2572.14 & 93.02 & 81.25 & 115.23 & 120.12 \\
\hline LSD $5 \%$ & 1.71 & 1.52 & 1.92 & 1.80 & 1.32 & 1.35 & 12.18 & \begin{tabular}{|l|}
10.23 \\
\end{tabular} & 2.56 & 2.45 & \begin{tabular}{|l|}
2.15 \\
\end{tabular} & 2.71 \\
\hline
\end{tabular}

increased plant height in Giza 86 and Giza 88 during 2013 season only.

In this respect, the obtained increase of these traits may be attributed to the expected role of pix and potassium treatments in the balance of vegetative growth and increased the numbers of leaves and branches and accumulation of different plant growth substances in different organs of the plants and effects of pix on photosynthesis, carbohydrate status, membrane integrity and nutrient uptake which have been documented and the results used to explain the mode of action (Guo et al.,1994). Pix is a compound that could promote, inhibit, or even modify some physiological processes and/or its ability to affect morphological traits. This compound has been developed and tested on cotton plants (Zhao and Oosterhuis, 2000 and Sawan et al., 2006).

Here, also it could be concluded that, despite that obvious and significant reduction in plant height in different pix treatments; branches and leaf number as well as the total leaf area in the same treatments significantly increased.

This result could be attributed to the fact that any growth inhibitor such as pix, paclobutrazol ...etc, in other meaning the gibberellins inhibitors strictly cause more cytokines creation (Opik and Rolfe, 2005). Thereby, more branches carrying a plenty of small leaves is attained. So, the largest leaf area accompanied with high chlorophyll content (Table 3) could be synthesizing more assimilates leading to role dry weight increases (Table 2). Therefore, under these circumstances more bolls and great yield could be expected (Table 3 ) with good quality of fiber properties (Tables 4, 5\& 6) Oosterhuis (1994).

\subsection{Yield components}

Data in Table (3) show that all applied treatments gave a significant increase in the number of fruiting branches, number of open bolls/plant, boll weight, seed cotton yield/plant and seed index that was true with the two $\mathrm{cv}$. during 2012 and 2013 seasons . Also, it could be noticed that the highest values of all these parameters existed with the treatment of Mepiquate chloride (Pix) at $200 \mathrm{mg} / \mathrm{l}+$ potassium citrate at $500 \mathrm{mg} / 1$ in Giza 86 and Giza 88 cultivars during 2012 and 2013 seasons. These results agree with those previously reported by Oosterhuis (1994), Mekki (1999), Biles and Cothren (2001) and Ram et al. (2001).

Here, it could be noticed that increases in the number of fruiting branches/plant, were accompanied with significant increase in each of bolls/plant, boll weight, seed cotton yield and seed index (Wu et al.,1985), in this respect 
Table (3): Effect of pix and potassium citrate on yield components in some Egyptian cotton, cultivars during 2012 and 2013 seasons.

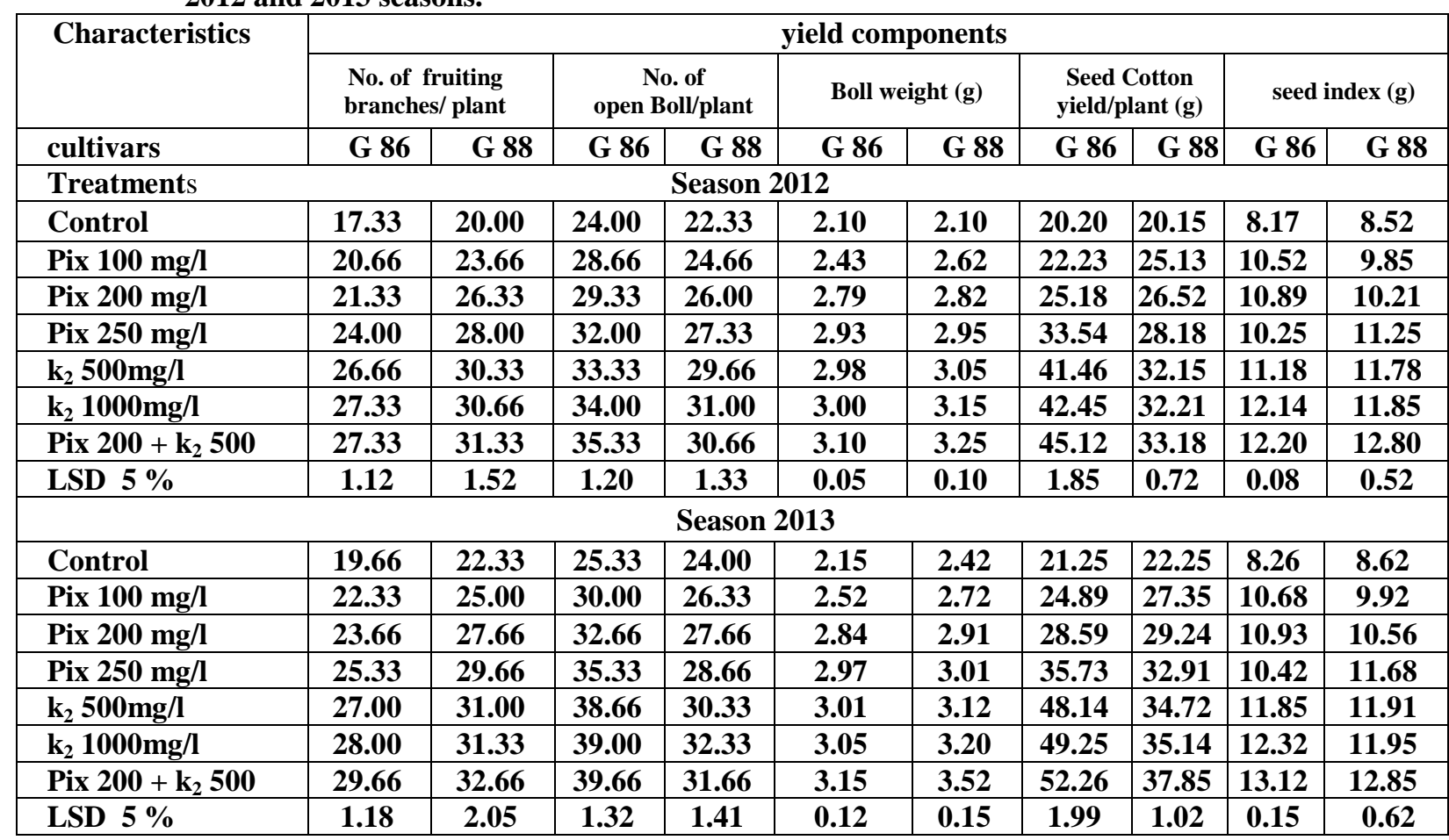

attributed the increases of different parameters in photosynthetic activity of leaves to potassium and pix application. Kler et al., (1989) stated that, increased photosynthesis increases flowering and boll retention. Also, Khan (1996) stated that plant growth regulators could be used for maintaining internal hormonal balance and an efficient sink source relationship that enhances crop productivity. Yield increases could be attributed to the effect of potassium on new growth and nutrient uptake (Fan et al., 1999), which caused favorable effects on the number of opened bolls per plant and boll weight, leading to higher cotton yield. Zeng (1996) indicated that K fertilizer reduced boll shedding. Potassium deficiencies can also limit the accumulation of crop biomass (Colomb et al., 1995). Potassium also has an important role in the translocation of photosynthesis from sources to sinks Cakmak et al.,(1994) and $\mathrm{Li}$ et al. (1999) reported that cellulose synthesis and dry matter accumulation increased by $\mathrm{K}$ application, which indicates that $\mathrm{K}$ deficiency during the reproductive period changes the structure of fruit-bearing organs and decreases yield and its quality.

The present results could support the foundation of Khan (1996) and Fan et al.(1999) for maintaining the internal hormonal balance and providing an efficient sink-source relationship since, increasing the number of fruiting branches and bolls as well as boll weight are established effect of improving cytokines creation and that could be in the present of sufficient amount of potassium could be a direct and true reason for that significant increases in different yield characteristics (Table 3). This physiological role of cytokines and potassium has been established by many researchers (Ahmed 2002, Opik and Rolfe, 2005 and A.S.T.M., 1998).

\subsection{Fiber and yarn properties}

Data in Tables $(4,5,6 \& 7)$ indicated that different applied treatments i.e. pix at 100, 200 and $250 \mathrm{mg} / \mathrm{l}$, potassium citrate at 500\& 1000 $\mathrm{mg} / \mathrm{l}$ and combination of Mepiquate chloride (Pix) at $200 \mathrm{mg} / \mathrm{l}+$ potassium citrate at $500 \mathrm{mg} / \mathrm{l}$ increased SL2.5\%, SL 50\%, UR \%, ML, UHM, UI\%, SL66.7\%, Rd\%, Elong, and STR. The highest value of these traits existed with combination of pix at $200 \mathrm{mg} / \mathrm{l}+$ potassium citrate at $500 \mathrm{mg} / \mathrm{l}$ in Giza 86 during 2012 and2013 seasons. On the other hand, different treatments decreased SFC \%, C.V\%, b, MIC, C.V\%, thin places, thick places and neps in Giza 86 during 2012 and 2013seasons. But, in Giza 88 different applied treatments increased SL $50 \%$, UR\%, UHM, SL 66.7\%, Elong\%, Mic and neps during 2012 and 2013 seasons. The maximum effective of these traits by using 
Table (4): Effect of pix and potassium citrate $\left(\mathrm{K}_{2}\right)$ on fiber properties in some Egyptian cotton cultivars during 2012 and 2013 seasons.

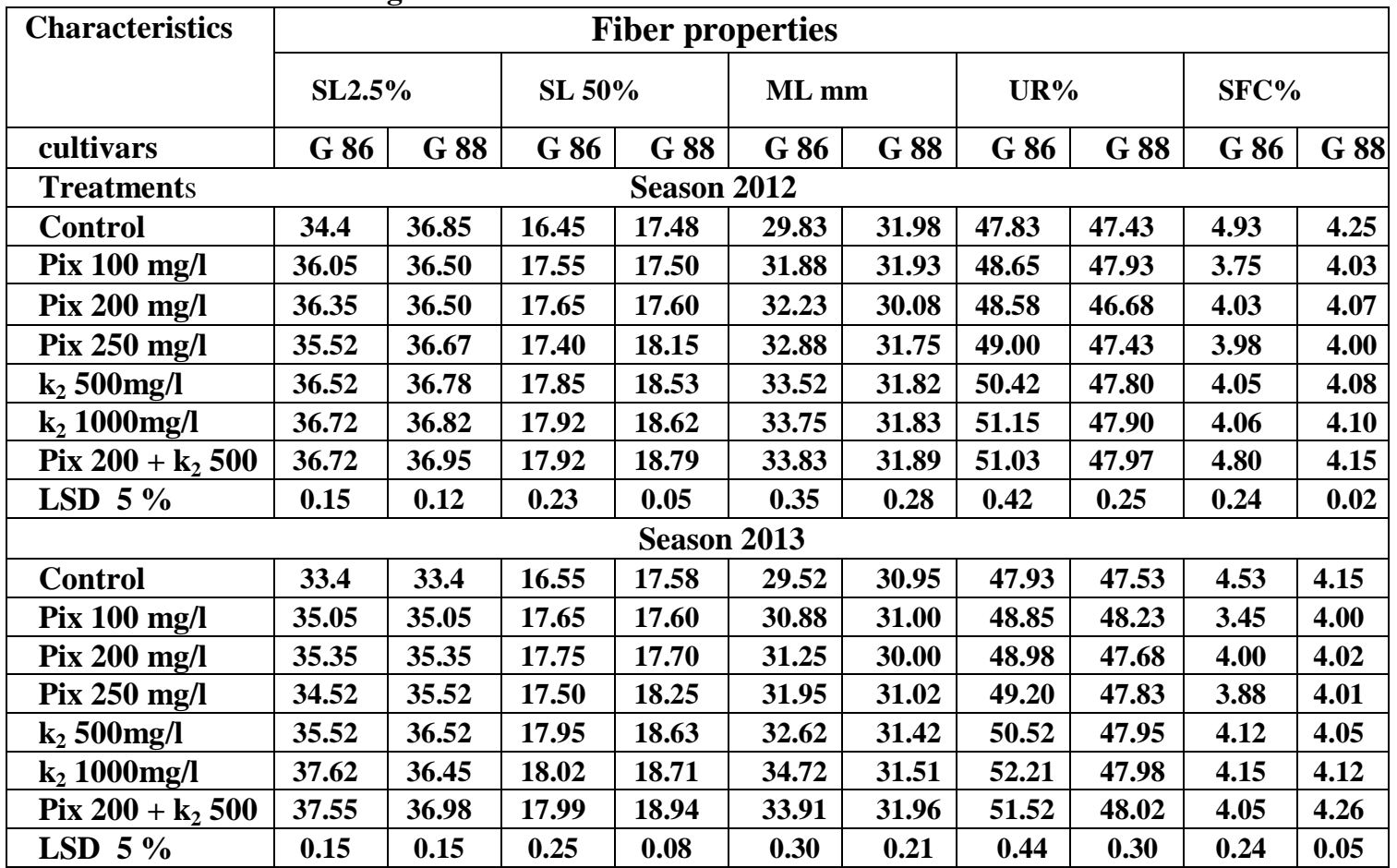

Table (5): Effect of pix and potassium citrate $\left(K_{2}\right)$ on fiber properties in some Egyptian cotton cultivars during 2012 and 2013 seasons.

\begin{tabular}{|c|c|c|c|c|c|c|c|c|c|c|}
\hline \multirow{3}{*}{$\begin{array}{l}\text { Characteristics } \\
\text { cultivars } \\
\end{array}$} & \multicolumn{10}{|c|}{ Fiber properties } \\
\hline & \multicolumn{2}{|c|}{ UHM m.m. } & \multicolumn{2}{|c|}{ UI\% } & \multicolumn{2}{|c|}{ SL66.7\% } & \multicolumn{2}{|c|}{ c.v\% } & \multicolumn{2}{|c|}{$+\mathbf{b}$} \\
\hline & G 86 & G 88 & G 86 & G 88 & G 86 & G 88 & G 86 & G 88 & G 86 & G 88 \\
\hline Treatments & \multicolumn{10}{|c|}{ Season 2012} \\
\hline Control & 34.68 & 36.70 & 86.20 & 87.13 & 12.23 & 12.90 & 26.08 & 26.33 & 11.40 & 10.43 \\
\hline Pix 100 mg/l & 36.93 & 37.05 & 86.35 & 86.18 & 12.95 & 12.93 & 24.68 & 25.40 & 10.20 & 11.28 \\
\hline Pix 200 mg/l & 37.30 & 37.48 & 86.40 & 84.83 & 12.98 & 12.33 & 25.08 & 27.55 & 10.00 & 10.53 \\
\hline Pix 250 mg/l & 48.38 & 36.73 & 87.93 & 86.43 & 12.80 & 12.83 & 24.53 & 25.63 & 10.18 & 11.20 \\
\hline $\mathrm{k}_{2} 500 \mathrm{mg} / \mathrm{l}$ & 50.32 & 36.82 & 88.54 & 85.35 & 12.99 & 12.96 & 25.41 & 25.50 & 10.30 & 11.52 \\
\hline $\mathrm{k}_{2}$ 1000mg/l & 51.42 & 36.84 & 88.58 & 85.45 & 13.00 & 12.97 & 25.52 & 25.65 & 10.40 & 11.61 \\
\hline Pix $200+k_{2} 500$ & 50.86 & 36.91 & 88.92 & 86.14 & 13.12 & 13.02 & 26.46 & 25.82 & 10.52 & 11.85 \\
\hline LSD $5 \%$ & 0.62 & 0.41 & 0.05 & 0.11 & 0.07 & 0.08 & 0.12 & 0.05 & 0.06 & 0.08 \\
\hline \multicolumn{11}{|c|}{ Season 2013} \\
\hline Control & 33.50 & 36.02 & 85.10 & 85.13 & 12.05 & 12.75 & 26.00 & 26.23 & 11.00 & 10.32 \\
\hline Pix 100 mg/l & 36.10 & 36.82 & 85.35 & 85.18 & 12.2 & 12.82 & 24.52 & 25.20 & 10.10 & 11.02 \\
\hline Pix 200 mg/l & 37.00 & 36.44 & 85.43 & 84.63 & 12.72 & 12.10 & 25.10 & 26.51 & 10.01 & 10.35 \\
\hline Pix 250 mg/l & 48.00 & 36.31 & 86.83 & 86.73 & 12.67 & 12.73 & 24.22 & 25.61 & 10.03 & 11.02 \\
\hline $\mathrm{k}_{2} 500 \mathrm{mg} / \mathrm{l}$ & 49.20 & 36.84 & 87.64 & 85.95 & 12.85 & 12.75 & 24.25 & 25.72 & 10.15 & 11.48 \\
\hline $\mathrm{k}_{2} 1000 \mathrm{mg} / \mathrm{l}$ & 49.25 & 36.91 & 87.71 & 85.98 & 12.91 & 12.82 & 24.60 & 25.78 & 10.23 & 11.51 \\
\hline Pix $200+k_{2} 500$ & 50.93 & 36.99 & 88.98 & 86.53 & 13.02 & 12.85 & 26.58 & 25.75 & 10.65 & 11.92 \\
\hline LSD $5 \%$ & 0.56 & 0.42 & $\mathbf{0 . 0 8}$ & 0.12 & 0.10 & 0.12 & 0.15 & 0.08 & 0.05 & 0.09 \\
\hline
\end{tabular}


Table (6): Effect of pix and potassium citrate $\left(\mathrm{K}_{2}\right)$ on fiber properties in some Egyptian cotton cultivars during 2012 and 2013 seasons.

\begin{tabular}{|c|c|c|c|c|c|c|c|c|}
\hline \multirow{3}{*}{$\begin{array}{l}\text { Characteristics } \\
\text { cultivars }\end{array}$} & \multicolumn{8}{|c|}{ Fiber properties } \\
\hline & \multicolumn{2}{|c|}{$\mathbf{R d} \%$} & \multicolumn{2}{|c|}{ Elongation \% } & \multicolumn{2}{|c|}{ Str. Gram/tex } & \multicolumn{2}{|c|}{ Mic. } \\
\hline & G 86 & G 88 & G 86 & G 88 & G 86 & G 88 & G 86 & G 88 \\
\hline \multicolumn{9}{|l|}{ Treatments } \\
\hline Control & 68.03 & 65.00 & 7.63 & 7.43 & 45.10 & 49.38 & 4.65 & 4.00 \\
\hline Pix 100 mg/l & 68.03 & 65.73 & 7.78 & 7.53 & 43.20 & 48.13 & 4.23 & 4.08 \\
\hline Pix 200 mg/l & 71.43 & 65.13 & 7.70 & 7.63 & 43.10 & 45.10 & 4.03 & 4.05 \\
\hline Pix 250 mg/l & 67.60 & 62.78 & 7.38 & 7.58 & 46.18 & 43.33 & 4.28 & 4.00 \\
\hline$k_{2} 500 \mathrm{mg} / \mathrm{l}$ & 68.85 & 63.52 & 7.81 & 7.73 & 47.15 & 48.50 & 4.45 & 4.23 \\
\hline $\mathbf{k}_{2} 1000 \mathrm{mg} / \mathrm{l}$ & 69.90 & 64.23 & 7.91 & 7.72 & 47.17 & 48.52 & 4.48 & 4.25 \\
\hline Pix $200+k_{2} 500$ & 69.15 & 63.72 & 7.92 & 7.81 & 47.22 & 48.60 & 4.42 & 4.32 \\
\hline LSD $5 \%$ & 0.15 & 0.06 & 0.05 & 0.09 & 0.05 & 0.12 & 0.08 & 0.12 \\
\hline \multicolumn{9}{|c|}{ Season 2013} \\
\hline Control & 67.82 & 65.10 & 7.55 & 7.41 & 44.00 & 48.40 & 4.52 & 3.95 \\
\hline Pix 100 mg/l & 68.00 & 67.56 & 7.76 & 7.26 & 43.10 & 48.50 & 4.15 & 4.05 \\
\hline Pix 200 mg/l & 71.23 & 68.10 & 7.62 & 7.45 & 42.18 & 45.20 & 4.00 & 4.00 \\
\hline Pix 250 mg/l & 67.72 & 62.52 & 7.48 & 7.50 & 45.60 & 43.42 & 4.02 & 4.02 \\
\hline $\mathrm{k}_{2} 500 \mathrm{mg} / \mathrm{l}$ & 69.20 & 63.42 & 7.82 & 7.65 & 46.25 & 48.32 & 4.25 & 4.18 \\
\hline $\mathrm{k}_{2} 1000 \mathrm{mg} / \mathrm{l}$ & 69.52 & 64.52 & 7.92 & 7.79 & 46.32 & 48.33 & 4.27 & 4.20 \\
\hline Pix $200+k_{2} 500$ & 69.82 & 63.82 & 7.95 & 7.75 & 46.35 & 48.71 & 4.32 & 4.25 \\
\hline LSD $5 \%$ & 0.20 & 0.09 & 0.08 & 0.12 & 0.08 & 0.13 & 0.10 & 0.13 \\
\hline
\end{tabular}

Table (7): Effect of pix and potassium citrate $\left(K_{2}\right)$ on yarn properties in some Egyptian cotton cultivars during 2012 and 2013 seasons.

\begin{tabular}{|c|c|c|c|c|c|c|c|c|c|c|}
\hline \multirow{3}{*}{\begin{tabular}{|l|} 
Characteristics \\
cultivars \\
\end{tabular}} & \multicolumn{10}{|c|}{$\begin{array}{ll}\text { Yarn properties } \\
\end{array}$} \\
\hline & \multicolumn{2}{|c|}{ Skein strength } & \multicolumn{2}{|c|}{ C.V.\% } & \multicolumn{2}{|c|}{ Thin Places } & \multicolumn{2}{|c|}{ Thick Places } & \multicolumn{2}{|c|}{ Neps } \\
\hline & G 86 & G 88 & G 86 & G 88 & G 86 & G 88 & G 86 & G 88 & G 86 & G 88 \\
\hline Treatments & \multicolumn{10}{|c|}{ Seasons 2012} \\
\hline Control & 2630 & 2850 & 16.96 & 16.54 & 9.00 & 4.00 & 20.00 & 15.00 & 11.00 & 6.00 \\
\hline Pix 100 mg/l & 2660 & 2870 & 16.80 & 16.50 & 7.00 & 3.00 & 17.00 & 13.00 & 9.00 & 5.00 \\
\hline Pix 200 mg/l & 2690 & 2890 & 16.75 & 16.41 & 6.75 & 3.00 & 16.00 & 12.00 & 8.00 & 9.00 \\
\hline Pix 250 mg/l & 2715 & 2920 & 16.62 & 16.35 & 4.00 & 2.50 & 17.00 & 10.00 & 6.75 & 8.00 \\
\hline $\mathrm{k}_{2} 500 \mathrm{mg} / \mathrm{l}$ & 2660 & 2885 & 16.92 & 16.45 & 7.75 & 3.72 & 18.00 & 14.00 & 9.85 & 10.00 \\
\hline $\mathrm{k}_{2} 1000 \mathrm{mg} / \mathrm{l}$ & 2645 & 2870 & 16.93 & 16.47 & 7.78 & 3.75 & 18.00 & 14.00 & 9.90 & 10.00 \\
\hline Pix $200+k_{2} 500$ & 2650 & 2865 & 16.95 & 16.46 & 7.82 & 3.82 & 19.00 & 14.00 & 9.95 & 11.00 \\
\hline \multirow[t]{2}{*}{ LSD $5 \%$} & 23.45 & 15.12 & 0.15 & 0.10 & 0.10 & 0.11 & 0.25 & 0.18 & 0.16 & 0.15 \\
\hline & \multicolumn{10}{|c|}{ Seasons 2013} \\
\hline Control & 2640 & 2855 & 16.96 & 16.20 & 9.00 & 4.02 & 20.00 & 15.05 & 11.00 & 5.00 \\
\hline Pix 100 mg/l & 2670 & 2885 & 16.80 & 16.15 & 7.00 & 3.02 & 7.00 & 13.04 & 9.00 & 4.00 \\
\hline Pix 200 mg/l & 2690 & 2860 & 16.75 & 16.32 & 6.75 & 3.05 & 16.00 & 12.06 & 8.00 & 8.00 \\
\hline Pix 250 mg/l & 2750 & 2895 & 16.62 & 16.25 & 4.00 & 2.58 & 17.00 & 10.18 & 6.75 & 7.00 \\
\hline$k_{2} 500 \mathrm{mg} / \mathrm{l}$ & 2630 & 2880 & 16.92 & 16.35 & 7.75 & 3.65 & 18.00 & 14.29 & 9.85 & 9.00 \\
\hline $\mathrm{k}_{2} 1000 \mathrm{mg} / \mathrm{l}$ & 2620 & 2870 & 16.93 & 16.40 & 7.78 & 3.73 & 18.00 & 14.30 & 9.90 & 9.00 \\
\hline Pix $200+k_{2} 500$ & 2600 & 2860 & 16.95 & 16.48 & 7.82 & 3.80 & 19.00 & 14.32 & 9.95 & 10.00 \\
\hline LSD $5 \%$ & 21.68 & 16.83 & 0.15 & 0.09 & 0.10 & 0.13 & 0.25 & 0.19 & 0.16 & 0.16 \\
\hline
\end{tabular}

potassium citrate at $500 \mathrm{mg} / \mathrm{l}$ during 2012 and 2013 seasons. On the other hand, different applied treatments decreased SL2,5, ML, UL \%, C.V. \% Rd, STR, C.V \%, Thin Places and Thick Places during 2012 and 2013 seasons
(Oosterhuis, 1994, Oosterhuis et al., 1990 and Elayan, et al. 2008).

In this respect, pix and potassium citrate increased the physiological processes in plant growth such as photosynthesis partitioning and 
accumulated and allocation from source to sink and which is believed to be related to the improved partitioning and accumulation of dry matter into fiber properts (Zhao and Oosterhuis, 2000).

It was reported that leaf carbohydrates represent the primary metabolic carbohydrate pools for cotton thus understanding their dynamics during cotton growth and boll development is important for fiber properties increases. It was stated that plant growth regulators (pix) can influence carbohydrate translocation out of the cotton leaf (source) to boll (sink) thereby increased yield and fiber properties. The slight effects of pix and potassium on fiber properties in this study, and the inconsistent effects in other searches, indicate that these treatments should be expected to have inconsistent and small effects that are not likely to be of economic importance.

\subsection{Nutrients content}

Data in Tables (8 and 9) show that Mepiquate chloride (Pix) at 100, 200, $250 \mathrm{mg} / 1$,potassium citrate at $500 \& 1000 \mathrm{mg} / \mathrm{l}$ and combination of pix at $200 \mathrm{mg} / \mathrm{l}+$ potassium citrate at $500 \mathrm{mg} / \mathrm{l}$ increased $\mathrm{N}, \mathrm{P}, \mathrm{K}, \mathrm{Mg}, \mathrm{Ca}, \mathrm{Fe}$ and $\mathrm{Cu}$ concentration in leaves of cotton plant cultivars Giza 86 and Giza 88 at 100 days after sowing during 2012 and 2013 seasons. The maximum effective of different minerals contents by using combination of pix at $200 \mathrm{mg} / \mathrm{l}+$ potassium citrate at $500 \mathrm{mg} / 1$ in Giza 86 and Giza 88 cotton cultivars during 2012 and 2013 seasons.

3.5. Carbohydrates and crude protein content

Data in Table (9) show that total carbohydrates and crude protein content significantly increased by using different applied treatments at 120 days after sowing in Giza 86 and Giza 88 during 2012 and 2013 seasons. In this context, the highest value of these traits was existed with combination of Mepiquate chloride (Pix) at 200mg/l + potassium citrate at $500 \mathrm{mg} / 1$ in Giza 86 and Giza 88 during 2012 and 2013 seasons.

Here, the obtained increase of minerals concentration, carbohydrates and crude protein contents may be attributed to the role of pix and potassium up on biochemical pathways of photosynthesis rates, stomata conductance in treated plants. Also, Pettigrew (1999) stated that, the elevated transpiration was positively correlated with leaf $\mathrm{N}$ and carbohydrate concentrations. Similar findings such as leaves, appear to be part of the overall. Palomo et al.,(1999), found that when potassium was applied, it increased different minerals uptake.

Since, leaf carbohydrates represent the primary metabolic carbohydrate pools for cotton plants,

Table (8): Effect of pix and potassium citrate $\left(K_{2}\right)$ on some macro element contents some Egyptian cotton cultivars during 2012 and 2013 seasons.

\begin{tabular}{|c|c|c|c|c|c|c|c|c|c|c|}
\hline \multirow[t]{2}{*}{ Characteristics } & \multicolumn{10}{|c|}{ Some macro element contents } \\
\hline & \multicolumn{2}{|c|}{$\mathbf{N} \%$} & \multicolumn{2}{|c|}{ P \% } & \multicolumn{2}{|c|}{ K \% } & \multicolumn{2}{|c|}{$\operatorname{Mg} \%$} & \multicolumn{2}{|c|}{ Сa \% } \\
\hline cultivars & G 86 & G 88 & G 86 & G 88 & G 86 & G 88 & G 86 & $\begin{array}{c}\mathbf{G} \\
88\end{array}$ & G 86 & G 88 \\
\hline \multicolumn{11}{|c|}{ Season 2012} \\
\hline Control & 1.55 & 1.44 & 0.50 & 0.62 & 1.35 & 1.45 & 0.20 & 0.22 & 0.42 & 0.35 \\
\hline Pix $100 \mathrm{mg} / \mathrm{l}$ & 1.92 & 1.52 & 0.66 & 0.73 & 1.75 & 1.65 & 0.59 & 0.67 & 0.52 & 0.45 \\
\hline Pix $200 \mathrm{mg} / \mathrm{l}$ & 1.99 & 1.95 & 0.74 & 0.78 & 1.95 & 1.75 & 0.65 & 0.72 & 0.65 & 0.59 \\
\hline Pix $250 \mathrm{mg} / \mathrm{l}$ & 2.15 & 2.29 & $\mathbf{0 . 8 3}$ & 0.85 & 2.23 & 2.13 & 0.72 & 0.75 & 0.72 & 0.72 \\
\hline$k_{2} 500 \mathrm{mg} / \mathrm{l}$ & 2.30 & 2.71 & 0.91 & 0.89 & 3.00 & 2.51 & 0.78 & 0.76 & 0.79 & 0.76 \\
\hline $\mathrm{k}_{2} 1000 \mathrm{mg} / \mathrm{l}$ & 2.35 & 2.73 & 0.92 & 0.90 & 3.01 & 2.53 & 0.79 & 0.78 & 0.80 & 0.77 \\
\hline Pix 200 + $k_{2} 500$ & 2.45 & 2.81 & 0.93 & 0.91 & $\mathbf{3 . 0 5}$ & 2.82 & 0.81 & 0.82 & 0.82 & 0.80 \\
\hline LSD $5 \%$ & 0.15 & 0.15 & 0.22 & 0.05 & 0.42 & 0.18 & 0.12 & 0.10 & 0.05 & 0.05 \\
\hline \multicolumn{11}{|c|}{ Season 2013} \\
\hline Control & 1.62 & 1.53 & 0.52 & 0.67 & 1.42 & 1.52 & 0.32 & 0.31 & 0.47 & 0.37 \\
\hline Pix $100 \mathrm{mg} / \mathrm{l}$ & 2.05 & 2.15 & 0.69 & 0.73 & 1.94 & 1.74 & 0.65 & 0.71 & 0.57 & 0.47 \\
\hline Pix $200 \mathrm{mg} / \mathrm{l}$ & 2.33 & 2.43 & 0.78 & 0.81 & 2.01 & 1.89 & 0.68 & 0.76 & 0.72 & 0.63 \\
\hline Pix $250 \mathrm{mg} / \mathrm{l}$ & 2.29 & 2.59 & 0.87 & 0.87 & 2.35 & 2.25 & 0.79 & 0.77 & 0.78 & 0.75 \\
\hline$k_{2} 500 \mathrm{mg} / \mathrm{l}$ & 2.52 & 2.82 & 0.90 & 0.92 & 3.02 & 2.71 & 0.82 & $\mathbf{0 . 8 3}$ & 0.85 & 0.85 \\
\hline $\mathrm{k}_{2} 1000 \mathrm{mg} / \mathrm{l}$ & 2.56 & 2.79 & 0.92 & 0.93 & 3.03 & 2.73 & 0.84 & 0.85 & 0.86 & 0.86 \\
\hline Pix $200+k_{2} 500$ & 2.72 & 3.01 & 0.99 & 0.95 & 3.12 & 2.85 & 0.86 & 0.86 & 0.91 & 0.91 \\
\hline LSD $5 \%$ & 0.41 & 0.21 & 0.23 & 0.09 & 0.55 & 0.23 & 0.15 & 0.13 & 0.13 & 0.13 \\
\hline
\end{tabular}


Table (9): Effect of pix and potassium citrate $\left(K_{2}\right)$ on mine elements, total carbohydrates and crude protein contents some Egyptian cotton cultivars during 2012 and 2013 seasons.

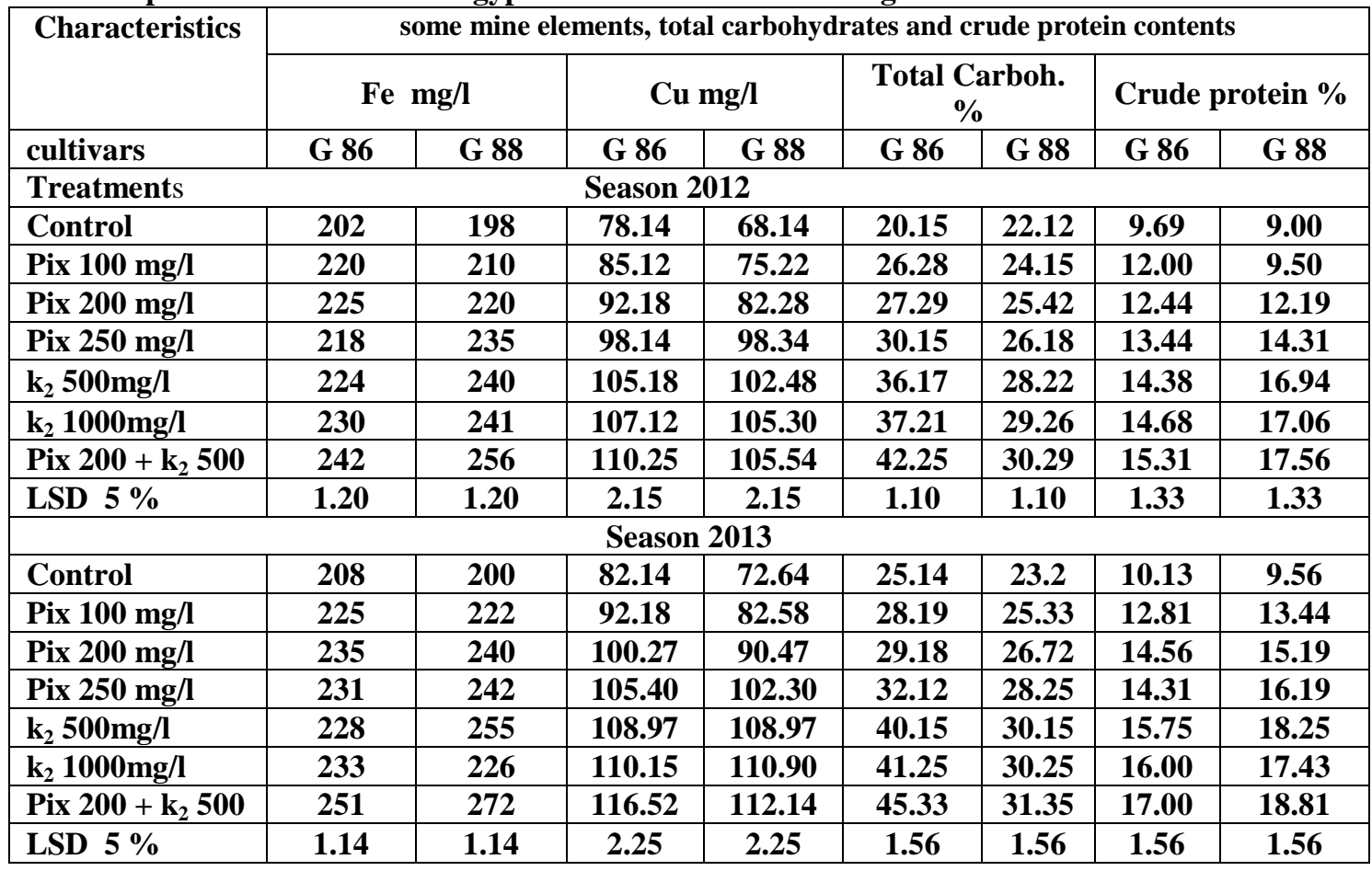

an understanding of their dynamics during cotton growth and boll development could be reported.

\section{Conclusions}

The maximum growth, yield and yield components, fiber properties, minerals and total carbohydrates \&crude protein contents were achived by using foliar application of combination of pix at $200 \mathrm{mg} / \mathrm{l}^{+}$potassium citrate at $500 \mathrm{mg} / \mathrm{l}$ through plant growth in the two Egyptian cotton cultivars Giza 86 and Giza 88. Therefore, the present study strongly suggest the use of such two treatments to improve each of cotton growth and the final yield with good quality as well.

\section{Acknowledgments}

The authors would like to thank Prof Dr: Said Ali El-Desouky Prof of plant physiology, Botany Dept., Fac. Agric. Benha University.

\section{REFFERANCES}

A.O. A. C. (1990).Official Method of Analysis, $15^{\text {th }}$ Ed., Association of Official Analytical Chemists, Inc., USA.

A.S.T.M. American Standard Testing and Materials (1998). On materials.D:157867:D:1425-60,D:1440-65,D1445-67,D:144868,D:2812-95.Annu. Book of ASTM Standard. ASTM. Philadelphia, PA.,USA.

Ahmed H.S.A. (2002). Botanical studies on growth and flower abortion in cotton
(Gossypium barbadense c.v) Plants. Msc. Dept. of Agric Botany. Fac. of Agric. Moshtohor, Zagazig Univ. Benha branch.

Ahmed H.S.A. (2010). Effect of some treatments on growth and productivity in Egyptian cotton. Ph.D.. Dept. of Agric Botany. Fac. of Agric. Moshtohor, Benha Univ.,Egypt.

Biles S.P. and Cothren J.T. (2001). Flowering and yield response of cotton to application of Mepiquate chloride and PGR-IV. Crop Sci., 41: 1834-1837.

Cakmak I., Hengeler C. and Marschner $\mathrm{H}$. (1994). Partitioning of shoot and root dry matter and carbohydrates in bean plants suffering from phosphorus, potassium and magnesium deficiency. J. Exp. Bot., 45: 1245-1250.

Colomb B., Bouniols A. and Delpech C. (1995). Effect of various phosphorus availabilities on radiation-use efficiency in sunflower biomass until anthesis. J. Plant Nutr., 18: 1649-1658.

Dubios M., Gilles K. A., Hamilton J.K., Rebens P.A. and Smith F. (1956). Colorimetric method for determination sugars and related substances. Anal. Chem. Soc., 46: 16621669.

Elayan S. E.D., Abdaallah A. M. and Abd ElMohsen A.A. (2008). Response of two Egyptian cotton cultivars to soil and foliar application of Potassium. Egypt. J. of Appl. Sci., 6A: 116-133. 
Fan S., Yuzhang X. and Chaojun Z. (1999). Effects of nitrogen, phosphorus and potassium on the development of cotton bolls in summer. Acta Gossypii Sinica 11: 24-30.

Guo C., Oosterhuis D.M. and Zhao D.(1994). Enhancing mineral nutrient uptake with plant growth regulators. Proc. $21^{s t}$ Annual Meeting Plant Growth Regulator Society of America. PP. 244-251.

Horneck D. A. and Hanson D. (1998). Determination of potassium and sodium by Flame Emission Spectrophotometer. In: Handbook of Reference Methods for Plant Anal.Library of Congress, USA. PP.153-155.

Horneck D. A. and Miller R. O. (1998). Determination of total nitrogen in plant tissue. In: Handbook of Reference Methods for Plant Anal,Library of Congress, USA.pp. 75-83.

Johnson R.E. (1967). Comparison of methods for estimating cotton leaf area. Agron. J., 59: 493-494.

KEISOKKI kcf-v/ls version 1.29.3. The following fiber properties were measured using Keisokki (2013). kcf-v/ls version 1.29.3. Instrument High volume fiber Length test system.

Khan N.A.(1996). Response of mustard to ethrel spray and basal and foliar application of nitrogen. J. Agron. Crop Sci., 175: 331-334.

Kler D.S., Raj D. and Dhillon G.S. (1989). Modification of micro-environment with cotton canopy for reduced abscission and increased seed yield. Environ. Ecol.,7: 800802.

Li F.S., Xu Y.Z. and Zhang C. (1999). Effects of nitrogen, phosphorus and potassium on the development of cotton bolls in summer. Acta Gossypii Sinica 11: 24-30.

Mekki B.B. (1999). Effect of Mepiquate chloride on growth, yield and fiber properties of some Egyptian cotton cultivars. Arab Univ. J. Agric. Sci., 7: 455-466.

Mohamed S. M.,El-Desouky S.A. and Wanas A.L.(2007). Response of Chlorophytumcomosum and Pepromiaclustfolii to some growth regulators Egypt. J. Sci.,7(6):625-645.

Najma A., Bano A., Ramzan S., Usman M.(2013). Effect of (VAM) on draught to clearance and growth of plant in comparison with the effect of growth regulators.Pakistan Journal of Biological Science , 3 (6): 957959.

Niakan Maryam A., Habibi A. and Mahlagha G. (2012). Study of Pix regulator effect on physiological responses in cotton plant. Annals of Biolo. Res., 3 (11): 5229-5235.

Oosterhuis D.M. (1994). Cotton growth regulators research and practical use in the USA 15-19. In: FAO Inter. Regional Cooperative research Network on cotton. Proceedings of the consultative meeting of the working. group 3 on growth regulators on cotton, 28-29 January 1994, Athens, Greece.

Oosterhuis D.M., Wullschleger S.D., Maples R.I. and Miley W.N. (1990). Foliar feeding of potassium nitrate in cotton. Better Crops with Plant Food. 74: 3, 8-9.

Opik H. and Rolfe S. (2005). The Physiology of flowering plants .Cambridge Univ.England.Pres 5.Plant Growth hormones. 177-194.

Palomo G. A., Godoy A. S. and Chavez G. J. F. (1999). Reductions in nitrogen fertilizers use with new cotton cultivars: yield, yield components and fiber quality. Agr. Ciencia., 33:451-455.

Pettigrew W.T., (1999). Potassium deficiency increases specific leaf weights of leaf glucose levels in fieldgrowncotton. Agron. J., 91: 962-968.

Ram P., Prasad M. and Pachauri D.K. (2001). Effect of nitrogen, mequat chloride and FYM on growth, yield and quality of cotton (Gossypium hirsutum L.). Ann. Agric. Res.,4: 107-110.

Sandell R. (1950). Colorimetric determination of traces of metal $2^{\text {nd }} \mathrm{Ed}$. Interscience pub., Inc. New York, USA.

Sangakkara U.R., Frehner M. and Nosberger J. (2000). Effect of soil moisture and potassium fertilizer on shoot water potential, photosynthesis and partitioning of carbon in mungbean and cowpea. Crop Sci. 8: 201-207.

Sawan Z. M., Mahmoud H. and El-Guibali Amal H. (2006). Response of yield, yield components, and fiber properties of Egyptian Cotton (Gossypium barbadense L.) to nitrogen fertilization and foliar-applied Potassium and mepiquat chloride (pix). The J. of Cotton Sci. 10: $224-234$.

Snedecor G.W., Cochran W.G.(1989). Statistical Methods. $8^{\text {th }}$ Edition, Iowa State Univ., Press, Ames, Iowa. USA.

Wu L.Y., Chen Z.H., Yuan Y.N. and Hu M. Y. (1985). A comparison of physiological effects of DPC and CCC on cotton plants. Plant Physiol. Commun, 5: 17-19.

Zeng Q. (1996). Experimental study on the 
efficiency of Kfertilizer applied to cotton in areas with cinnamon soil oraquic soil. China Cottons, 23: 12.

Zhao D. and Oosterhuis D.M. (2000). Pix Plus and mepiquat chloride effects on the physiology, growth and yield of field-grown cotton. J. Plant Growth Regulation, 20 (in press).

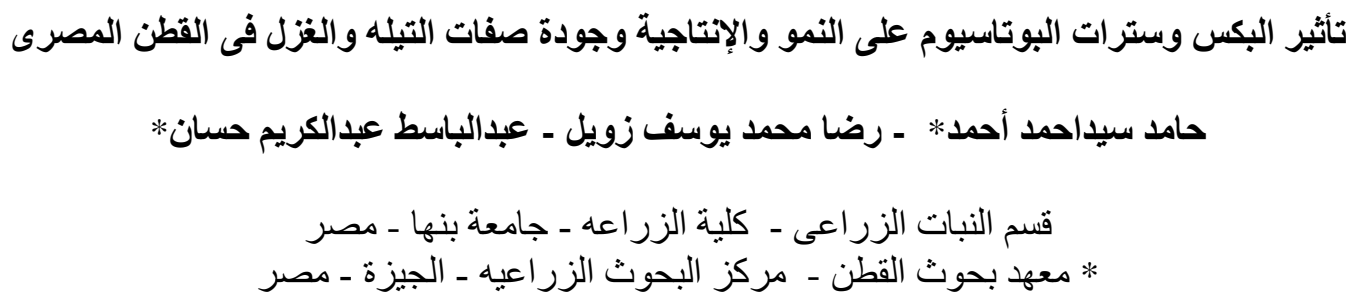

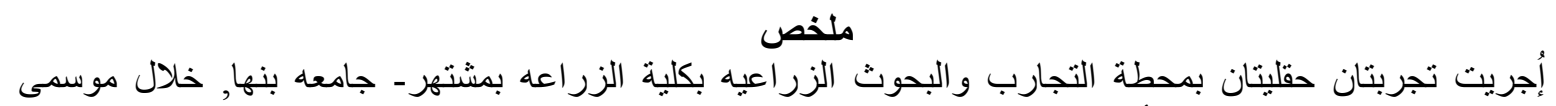

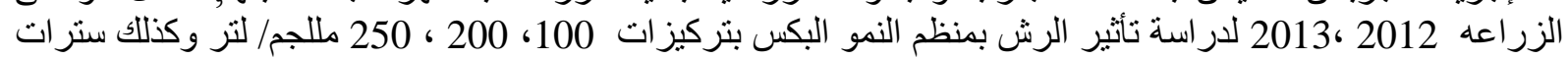

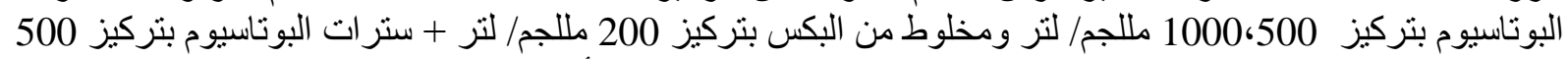

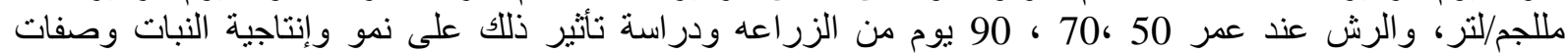

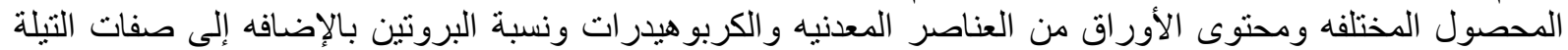

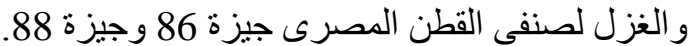

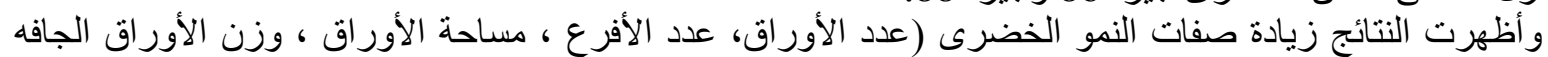

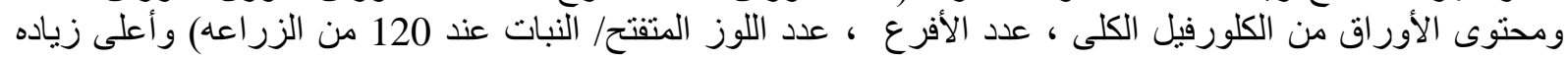

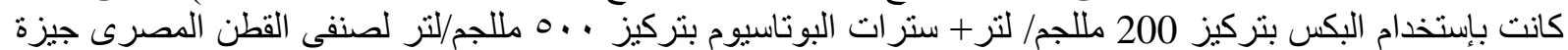
86 وجيزة 88 في كلا الموسمين).

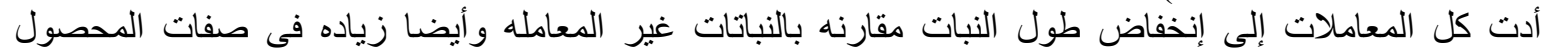

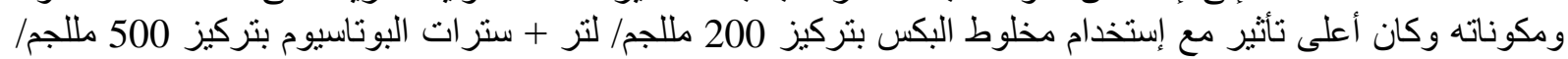

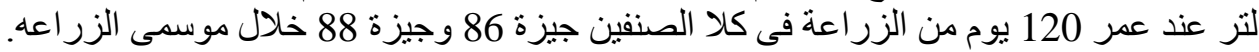

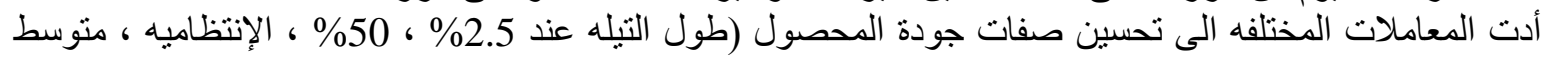

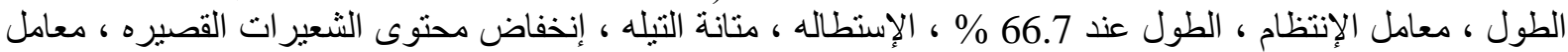

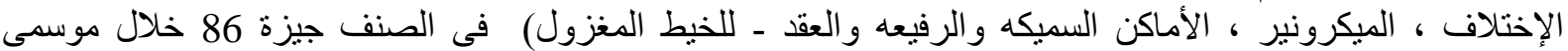

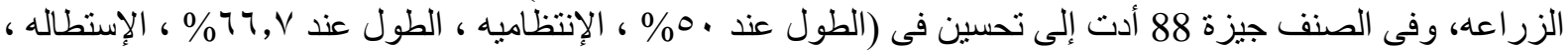
العقد للخيط المغزول) و أنخفض طول الزفه التيله عند 2.5\% ، متوسط الطول ، معامل الإختلاف ، المتانه ، الأماكن السميكه الإله

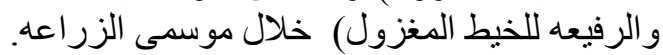

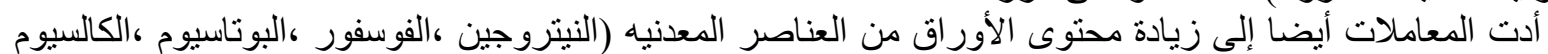

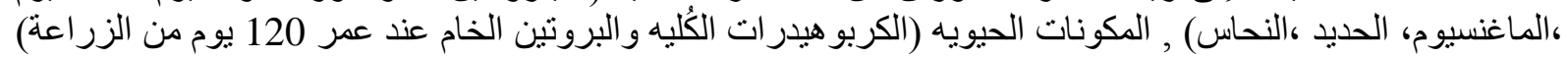

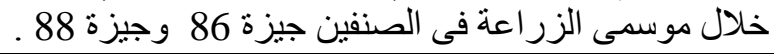

